\title{
The 2021 WCLR Student Award Winners
}

The Editorial Board of the Wrongful Conviction Law Review is pleased to announce the winners of the 2021 Student Awards as follows:

Gold Prize - Esti Azizi, University of Ottawa, Canada

"Maintaining Innocence: The Prison Experiences of the Wrongfully Convicted"

Silver Prize - Víctor Beltrán-Román, Diego Portales University, Chile "Innocent in the dark: Toward a Duty to Preserve Biological Evidence in Chilean Criminal Justice

Bronze Prize - Rhanee Rego, The University of Newcastle, N.S.W., Australia

"A Critical Analysis of Post-Conviction Review in New South Wales, Australia" 